\title{
=l usm $\sim$

\section{Educação, linguagem e teatro no âmbito da formação universitária: dos lugares teóricos e práticos da cri[ação] pedagógica e artística}

Education, language and theater in the context of university education: the theoretical and practical places of pedagogical and artistic creation

Cristiane do Rocio Wosniak

Professora Doutora da Universidade Federal do Paraná e Universidade Estadual do Paraná, Curitiba, Paraná, Brasil.

cristianewosniak@bol.com.br - http://orcid.org/0000-0002-7234-2638

Recebido em 07 de janeiro de 2019

Aprovado em 09 de janeiro de 2019

Publicado em 30 de junho de 2021

\section{RESUMO}

Trata-se de uma resenha crítica sobre o livro Teatro e Universidade: Cena. Pedagogia. [Dialogismo] do autor Jean Carlos Gonçalves, publicado em 2019 pela Editora Hucitec, compondo o número 23 da Coleção Pedagogia do Teatro.

Palavras-chave: Educação; Linguagem; Arte.

\section{ABSTRACT}

This is a critical review of the book Teatro e Universidade: Cena. Pedagogia. [Dialogismo] by the author Jean Carlos Gonçalves, published in 2019 by Editora Hucitec, composing number 23 of the Pedagogia do Teatro Collection.

Keywords: Education; Language; Art.

\section{Introdução}

O livro Teatro e Universidade: Cena. Pedagogia. [Dialogismo], de Jean Carlos Gonçalves, lançado em 2019 pela Editora Hucitec - compondo o vigésimo terceiro volume da série Pedagogia do Teatro -, configura-se, inicialmente, como uma publicação resultante de sua tese de doutorado, mas que adquiriu o olhar da revisão e da atualização forjado a partir de dois estágios de pós-doutorado realizados no âmbito do Programa de Estudos Pós-Graduados da Pontifícia Universidade Católica de São Paulo, sob a supervisão de Beth Braith - responsável pelo sensível texto de 


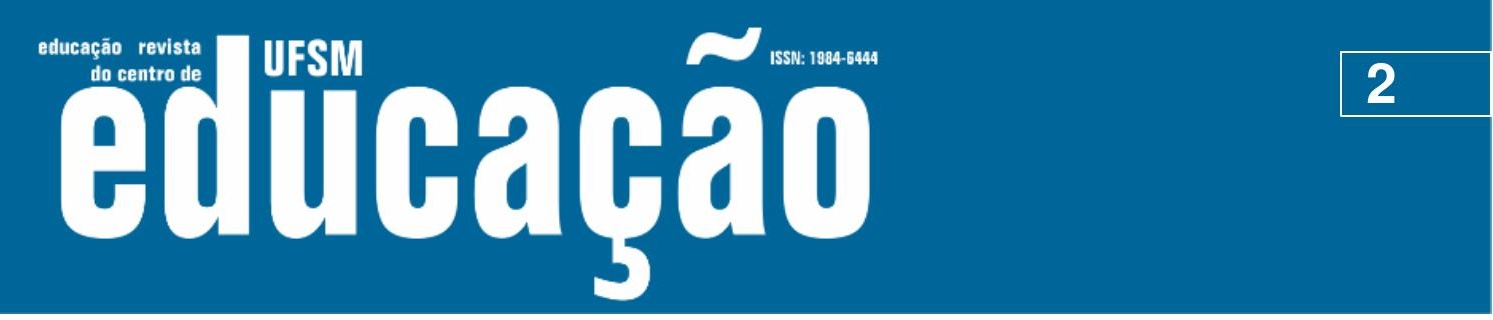

ISSN: 1984-6444 | http://dx.doi.org/10.5902/1984644441752

apresentação do livro.

O autor, que é Doutor e Mestre em Educação, ator e diretor de teatro, também atua como Professor na Universidade Federal do Paraná (UFPR), lecionando disciplinas cujos conteúdos perpassam as áreas de Linguagem, Corpo e Teatro, tanto na Graduação em Produção Cênica (SEPT/UFPR), quanto no âmbito do Programa de Pós-Graduação - Mestrado e Doutorado - em Educação (PPGE/UFPR) - vinculandose à Linha de Pesquisa LICORES (Linguagem, Corpo e Estética na Educação). Gonçalves também é docente do Programa de Mestrado Profissional em Educação: Teoria e Prática de Ensino (PPGE-Tpen/UFPR) e líder do Laboratório de Estudos em Educação Performativa, Linguagem e Teatralidades (ELiTe/UFPR/CNPq), além de diretor do CARMEN Group (Centro de Treinamento em Corpo, ARte, Movimento e ENcenação) na UFPR.

A presente obra coloca em discussão os densos conceitos e reflexões de Mikhail Bakhtin e do Círculo - especificamente a Análise Dialógica do Discurso (ADD) - para apresentar o pensar e o fazer teatro no contexto do ensino superior, decifrado por meio das dimensões verbo-visuais descritas pelos sujeitos da aprendizagem alunos-atores do curso de Bacharelado em Teatro-Interpretação da Universidade Regional de Blumenau (FURB) -, ao escreverem sobre os processos vivenciados in locus, quando da montagem de espetáculos teatrais no decurso de suas formações em teatro.

Trata-se de um livro que apresenta uma temática ainda pouco explorada no universo acadêmico e nas pesquisas da grande área da Educação. Em uma tentativa original e metodologicamente rigorosa - pesquisa que incorpora os pressupostos da investigação qualitativa em educação -, o autor aproxima, de fato, a educação [ensino-aprendizagem/formação em teatro], a linguagem (ADD) e as Artes da Cena [processo de criação/encenação de um espetáculo teatral], no momento em que se reporta às vozes, ou melhor, aos enunciados dos seus alunos - agentes da prática cênica - para entender e refletir sobre os supostos processos de construção de sentidos da educação e do teatro. E de que que modo e com que meios Gonçalves empreende o percurso gerativo da investigação? 


\section{HSW Guthragáo

ISSN: 1984-6444 | http://dx.doi.org/10.5902/1984644441752

os possíveis sentidos daí extraídos a partir de menções ao espaço/sala de aula como lugar físico de acontecimento das montagens - e ao tempo/durante as aulas lugar da preparação corporal, dos jogos, dos ensaios, das trocas perceptivas, do diálogo, das oficinas - concluindo que nestes indicativos verbais ocorre uma aproximação efetiva entre as vozes do teatro e da educação.

O capítulo 2 da Parte II traz o título de Vozes do teatro na educação e as reflexões são tecidas a partir do complexo conjunto de enunciados que se referem aos diferentes sentidos do teatro na contemporaneidade. Estruturado em 3 seções, a saber: 2.1) Processos colaborativos de criação cênica: uma utopia?; 2.2) Encenação teatral: qual é mesmo o modelo?; 2.3) Teatro de grupo: somos um grupo?, o autor encena a cada final dos títulos das seções um ponto de interrogação. E é na/da interrogação que este capítulo se reveste ao trazer para o foco da cena duas questões: "quais as tendências contemporâneas no fazer teatral que acabam sendo recorrentes na prática universitária? Como os modelos de teatro feitos fora da universidade acabam constituindo as trajetórias criativas nessa esfera?" (GONÇALVES, 2019, p. 115). O autor aposta em uma reflexão pautada na precisão sobre a criação cênica como um espaço/lugar no qual as vozes da educação e do teatro, em relação dialógica, estão presentes.

Finalizando a obra, o texto Ensaio aberto traz as considerações finais sobre o processo investigativo, assumindo o seu "não acabamento e sua incompletude" (GONÇALVES, 2019, p. 22), como requerem os pressupostos de um estudo bakhtiniano.

Diante da inegável lacuna existente no campo dos estudos teatrais no que tange às afinidades e semelhanças entre o teatro, a educação e a linguagem e, especificamente, nas concepções metodológicas que vislumbram a prática educativa em teatro a partir da linguagem, o livro Teatro e Universidade: Cena. Pedagogia. [Dialogismo], de Jean Carlos Gonçalves, certamente contribui para a área da Educação ao lançar um olhar crítico para os processos educacionais presentes na montagem teatral no âmbito do ensino superior e também para os processos de performance teatral que acontecem no âmbito formativo e educacional. 


\section{Try

ISSN: 1984-6444 | http://dx.doi.org/10.5902/1984644441752

\section{Referência}

GONÇALVES, Jean Carlos. Teatro e universidade: cena. pedagogia. [dialogismo]. São Paulo: Hucitec Editora, 2019. 172p. - Coleção Pedagogia do Teatro, № 23.

\section{(@) $(1) \Theta$}

This work is licensed under a Creative Commons Attribution-NonCommercial 4.0 International (CC BY-NC 4.0)

\section{Nota}

${ }^{1}$ Expressão que denomina o conjunto das produções dos autores [estudiosos de Mikhail Bakhtin e do Círculo] que desenvolveram a perspectiva dialógica da linguagem. 